\title{
Études balkaniques
}

Cahiers Pierre Belon

3 | 1996

Unité et diversité des cultures populaires du Sud-Est européen

\section{Irregular Military Bands and Colonies in the Balkans under Ottoman Rule 1789-1878}

Groupes d'irréguliers et colonies dans les Balkans ottomans 1789-1878

James J. Reid

\section{(2) OpenEdition}

\section{Journals}

Electronic version

URL: http://journals.openedition.org/etudesbalkaniques/386

ISSN: 2102-5525

\section{Publisher}

Association Pierre Belon

\section{Printed version}

Date of publication: 1 January 1996

Number of pages: 131-165

ISBN: 2-910860-03-5

ISSN: $1260-2116$

Electronic reference

James J. Reid, «Irregular Military Bands and Colonies in the Balkans under Ottoman Rule

1789-1878 », Etudes balkaniques [Online], 3 | 1996, Online since 08 April 2009, connection on 22 April 2019. URL : http://journals.openedition.org/etudesbalkaniques/386

This text was automatically generated on 22 April 2019

Tous droits réservés 


\section{Irregular Military Bands and Colonies in the Balkans under Ottoman Rule 1789-1878}

Groupes d'irréguliers et colonies dans les Balkans ottomans 1789-1878

James J. Reid

\section{ABSTRACTS}

Who were the irregulars at that time? In which extent do they have contributed to the Ottoman Empire's collapse? The author first answers to these two questions by describing the composition and the functioning of these military bands intervening most of all in intercommunity conflicts (vendetta, vigilante). Then several case studies are given, from Anatolia to the Balkans.

Qui étaient les irréguliers de cette époque ? En quoi ont-ils contribué à la disparition de l'empire ottoman? L'auteur répond d'abord à ces deux questions en décrivant composition et fonctionnement de ces groupes de militaires intervenant le plus souvent dans les conflits intercommunautaires (vendetta, vigilante). Il mène ensuite des études de cas aussi bien en Anatolie que dans les Balkans.

\section{AUTHOR}

JAMES J. REID

Vryonis Center 